\title{
SORTATION IN ECOMMERCE LOGISTICS IN INDIA: DESIGN PRINCIPLES FOR SCALABILITY \& FLEXIBILITY
}

\author{
*Nikhil $\operatorname{Vartak}^{1}$ and $*$ Swadesh Srivastava ${ }^{2}$ \\ *Flipkart Internet Private Ltd.Bangalore, Karnataka 560034, India
}

\begin{abstract}
The choice of sorting automation needs to be based on trade-offs on cost economics, reliability and operational challenges. A greater degree of warehouse maturity is required to handle increasing throughputs. While generally the per-unit-cost of operation will reduce as warehouse move towards greater degree of mechanization and automation, costs are also dependent on local factors. At the same time, awareness of the tipping point is essential to maintain low cost of operations with the promised level od service. This becomes even more essential for low-margin sectors like ecommerce logistics and low-wages countries like India.
\end{abstract}

Given this, key questions that we need to answer on Sortation are:

1. Network design related:

1. What is the right sort philosophy - sort at source vs. sort at destination vs. hybrid?

2. What factors will govern the choice of sorting centre locations?

2. Asset strategy related:

a. What is the asset cost-structure and accordingly the right technology for future sort requirements?

b. How can we modularize the investment to handle peaks \& scalability while factoring in practical constraints like land availability in urban areas?

The answer to above questions might change from industry to industry. As we scale beyond lowthroughput sorters at Flipkart, we have analysed and answered some of these questions to build applicable strategies and business cases

Keywords: Sorting, Network, Technology

\section{Introduction}

A typical supply chain network comprises of warehousing, First Mile, MotherHub, Delivery Hub. Mother hub or the sortation centre is a critical node in supply chain given that all the shipments have to flow through sortation centres and has to orchestrate for SLAs and variations upstream and downstream. A critical portion of world-class supply chain design is network, process and automation design of sortation centres..... Lets look at the network design portion of the puzzle first

Network Design: The major portions of network design are sort philosophy andtailoring for various types of services.
Sort Philosophy: The choice of sorting philosophy is based on trade-offs on cost economics and need for flexibility. Table 1 analyses the pros \& cons of both the philosophies.

1. Sort at Source

- Sort for the final destinations at source

- Involves lower touches and eases downstream operations

2. Sort at Destination

- Sort for the next node in the system

- Manages very high throughput and sort locations 
Table 1. Sort Philosophies

\begin{tabular}{|l|l|l|}
\hline Parameter & Sort at source & Sort at destination \\
\hline $\begin{array}{l}\text { Packaging Cost(material and } \\
\text { manpower for bagging) }\end{array}$ & Lower due to bagging at one location & $\begin{array}{l}\text { Higher due to duplication at both the } \\
\text { nodes }\end{array}$ \\
\hline Sorting Time & $\begin{array}{l}\text { Will be longer with higher complexity } \\
\text { of sorts and increased odds of choking } \\
\text { at hubs }\end{array}$ & $\begin{array}{l}\text { Dual packaging and handling will add } \\
\text { to the sorting time but hub choking is } \\
\text { minimized }\end{array}$ \\
\hline Flexibility -Direct DH & $\begin{array}{l}\text { Can deliver directly to high demand } \\
\text { DHs }\end{array}$ & $\begin{array}{l}\text { Rigid structure -Cannot deliver to high } \\
\text { demand MHs }\end{array}$ \\
\hline Error Rates & $\begin{array}{l}\text { Higher due to very high complexity at } \\
\text { one stage }\end{array}$ & $\begin{array}{l}\text { Lower due to moderate range of sorts } \\
\text { at both stages }\end{array}$ \\
\hline
\end{tabular}

Postal networks do sort at destination; Courier \& express players adopt a mix of sort at destination and source as tabled below.

Table 2. Postal \& CEP

\begin{tabular}{|c|c|c|c|c|}
\hline & Shipments per day & Delivery Hubs & Sorting Centres & Sort Philosophy \\
\hline \multicolumn{5}{|l|}{ Postal } \\
\hline USPS & $\begin{array}{l}500 m+d o c s \text { and } \\
\text { non-docs in the US }\end{array}$ & $\begin{array}{l}30,000+\text { post } \\
\text { offices }(\sim 150-250 \\
\text { post office per } \\
\text { sorting centre) }\end{array}$ & $\begin{array}{l}200+\text { sorting } \\
\text { centres }\end{array}$ & $\begin{array}{l}\text { Sortingat } 2 \text { nodes } \\
\text { Sort at source sorting centrefor } 150-200 \\
\text { destination sorting centre } \\
\text { Sort at destination sorting centrefor } 150 \text { - } \\
250 \text { post offices }\end{array}$ \\
\hline $\begin{array}{l}\text { India } \\
\text { Post }\end{array}$ & $\begin{array}{l}16 \mathrm{~m}+\text { docs and non } \\
\text { docs in India }\end{array}$ & $\begin{array}{l}1,50,000+\text { post } \\
\text { offices }\end{array}$ & $\begin{array}{l}75-80 \text { sorting } \\
\text { centres }\end{array}$ & $\begin{array}{l}\text { Sortingat } 2 \text { nodes } \\
\text { Sort at source sorting centrefor } 75-80 \\
\text { destination sorting centres } \\
\text { Sort at destination sorting centrefor } 1500 \text { - } \\
2000 \text { post offices }\end{array}$ \\
\hline \multicolumn{5}{|c|}{ CEP: Courier, express, Parcel } \\
\hline $\begin{array}{l}\text { UPS/Fe } \\
\mathrm{dEx}\end{array}$ & $\begin{array}{l}15 \mathrm{~m}+\text { docsand non } \\
\text { docs in the US }\end{array}$ & $\begin{array}{l}20,000+\text { delivery } \\
\text { branches }\end{array}$ & Not disclosed & $\begin{array}{l}\text { They adopt a dynamic sorting approach - } \\
\text { sort next node in their network as well as a } \\
\text { few key high demand lanes ("Jackpot } \\
\text { lanes") to balance their high throughput } \\
\text { and sort requirements }\end{array}$ \\
\hline DTDC & $\begin{array}{l}1 \text { lakh non docs in } \\
\text { India }\end{array}$ & $\begin{array}{l}300 \text { delivery } \\
\text { branches }\end{array}$ & $\begin{array}{l}\text { 15-30sorting } \\
\text { centres }\end{array}$ & $\begin{array}{l}\text { They sort at the source sorting centrefor } \\
\text { the next sorting centre }\end{array}$ \\
\hline
\end{tabular}

Sort at destination becomes cheaper when the sort threshold for a particular technology or manual setup is reached. The same is highlighted in the following table. SAS favourable for retail....high volume, less destinations...

NDD, SDD $\rightarrow$ SAS gives speed 
Table 3. Sort Destinations

\begin{tabular}{|l|l|l|}
\hline No. of Destinations & \multicolumn{2}{|l|}{$\begin{array}{l}\text { 80K per day BAU- (Designed for } \\
\text { 1.5x, 1 Shift Operation for an } \\
\text { inbound skew of 1.3 hourly } \\
\text { lean:peak) }\end{array}$} \\
\hline & $\begin{array}{l}\text { Sort @ Source } \\
\text { CPS }\end{array}$ & $\begin{array}{l}\text { Sort @ } \\
\text { Destination CPS }\end{array}$ \\
\hline 250 & $5.7-6.2$ & $6.8-7.3$ \\
\hline 500 & $5.7-6.2$ & $6.9-7.3$ \\
\hline 750 & $6.5-7.1$ & $7.8-8.5$ \\
\hline 1000 & $16.0-16.5$ & $13.0-13.5$ \\
\hline
\end{tabular}

\section{Learnings}

Build flexibility in sorting solution to sort for optimal number of destinations at each mother-hub based on through-put requirement.
Maximize number of sorts at hub through dynamic bin allocation and managing in-bound waves. $\rightarrow$ based on the load pattern of destinations

\section{Sort Centre Tailoring for various types of services}

Sorting requirements should be clubbed for scale benefits as well reducing the inbound skew of the FA and non FA shipments. But in scenarios where clubbing is not possible due to practical considerations like land availability etc., the following options are available.

Table 4. Sort Tailoring

\begin{tabular}{|c|c|c|c|}
\hline Options & Pros & Cons & Model \\
\hline Local and Non Local & $\begin{array}{l}\text { Reduction in number of sort } \\
\text { destinations } \\
\text { Enables faster local to local } \\
\text { marketplace shipments }\end{array}$ & $\begin{array}{l}\text { Process change required at } \\
\text { the FC -segregating at the } \\
\text { time of picking to avoid } \\
\text { merge of local/non local } \\
\text { orders }\end{array}$ & $\begin{array}{l}\text { Segregation at Pickup Hubs and sent } \\
\text { to the resp. MHs } \\
\text { The FC MH will send unsorted } \\
\text { shipments directly to the local } \mathrm{MH} \\
\text { enabled by local wave picking or } \\
\text { dedicated local pickers }\end{array}$ \\
\hline FA and NonFA & $\begin{array}{l}\text { Enables faster local to local } \\
\text { marketplace shipments }\end{array}$ & $\begin{array}{l}\text { Loss of flexibility to reduce } \\
\text { the skew of inbound } \\
\text { No reduction in sort } \\
\text { destinations }\end{array}$ & $\begin{array}{l}\text { FC MH caters to FAload \& sends } \\
\text { unsorted shipments directly to the } \\
\text { local MH } \\
\text { MP MH caters to non FA load. } \\
\text { Segregation at Pickup Hubs and sent } \\
\text { to the resp. MHs }\end{array}$ \\
\hline
\end{tabular}

\section{Learnings}

Local vs. Non local tailoring is recommended if clubbing of requirements is not possible. $\rightarrow$ geographical demand pattern

FA vs Non FA tailoring is governed solely by business needs \& supply chain construct.

\section{Facility Design Strategy}

\section{Sorting Technologies}

A variety of sorting technologies are available to support different sort complexity and through-put requirement. Emerging market players have been late technology adopters -and are considering automation only now. This paper talks about the various factors and trade-offs in selecting sorting technologies. There is a wide range of options in sorting technologies. Some of the typical ones are:

Manual - manual segregation of shipments by scanning the shipment IDs using scanners/hand held devices.

Linear Sorter - pneumatic arm based lowthrough put primary sorting equipment used to sort items using dynamic sorting logic. As the name suggests, the destinations are arranged linearly, in a straight line.

Tilt tray Sorter - tray-based medium throughput system arranged as an endlessloop. Mostly used as baggage or shipping sorter.

Cross Belt Sorter - casket-based high throughput system arranged as an endlessloop. The system is well-suited for operations in areas with limited space or challenging layouts and high number of enddestination sorts. 
Table 5 Compares the above technologies and their applicability.

Table 5. Sorting Technologies

\begin{tabular}{|l|l|l|l|l|}
\hline Type & Manual & $\begin{array}{l}\text { Linear } \\
\text { Sorter }\end{array}$ & $\begin{array}{l}\text { Tilt- } \\
\text { Tray } \\
\text { Sorter }\end{array}$ & $\begin{array}{l}\text { Cross- } \\
\text { Belt } \\
\text { Sorter }\end{array}$ \\
\hline $\begin{array}{l}\text { Capex (mio } \\
\text { INR) }\end{array}$ & $\sim 2$ & 10 & 100 & 180 \\
\hline $\begin{array}{l}\text { Throughput } \\
\text { per hour }\end{array}$ & $2 \mathrm{~K}$ & $3 \mathrm{~K}$ & $10 \mathrm{~K}$ & $15 \mathrm{~K}$ \\
\hline $\begin{array}{l}\text { Optimum } \\
\text { Sorts }\end{array}$ & $\begin{array}{l}10 \text { per } \\
\text { person }\end{array}$ & 20 & 100 & 200 \\
\hline $\begin{array}{l}\text { Area } \\
\text { required } \\
\text { (sq feet) }\end{array}$ & $\begin{array}{l}\text { 6 per bin } \\
\text { (w/o aisle } \\
\text { space) }\end{array}$ & $4 \mathrm{k}$ & $15 \mathrm{k}$ & $25 \mathrm{k}$ \\
\hline $\begin{array}{l}\text { Products } \\
\text { Handled }\end{array}$ & $\begin{array}{l}\text { Cansupport } \\
\text { multiple } \\
\text { dimensions } \\
\text { and } \\
\text { product } \\
\text { types }\end{array}$ & $\begin{array}{l}\text { Mostly } \\
\text { boxes, } \\
\text { does } \\
\text { not } \\
\text { work } \\
\text { too well } \\
\text { with } \\
\text { non-flat } \\
\text { surfaces } \\
\text { like } \\
\text { poly } \\
\text { bags }\end{array}$ & $\begin{array}{l}\text { Wide range incl. } \\
\text { apparel, small } \\
\text { items in poly bags, } \\
\text { CD's and small to } \\
\text { large corrugated } \\
\text { boxes }\end{array}$ \\
\hline
\end{tabular}

\section{Criteria to determine level of Automation}

Cost Economics - Operations and staging area costs. Factors that impact cost economics:

- Inbound window -Duration of inbound

- Inbound skew -Peak to average ratio of skew

- Number of sort destination

- Sortation SLA

Flexibility \& Reliability -

- Ability to handle differing volumetric profile of products

- Accuracy

- Reliability (up-time)

Operational aspects - Other operational considerations

- Challenges of managing a large workforce

- Space constraints, especially in large cities

\section{Cost Economics}

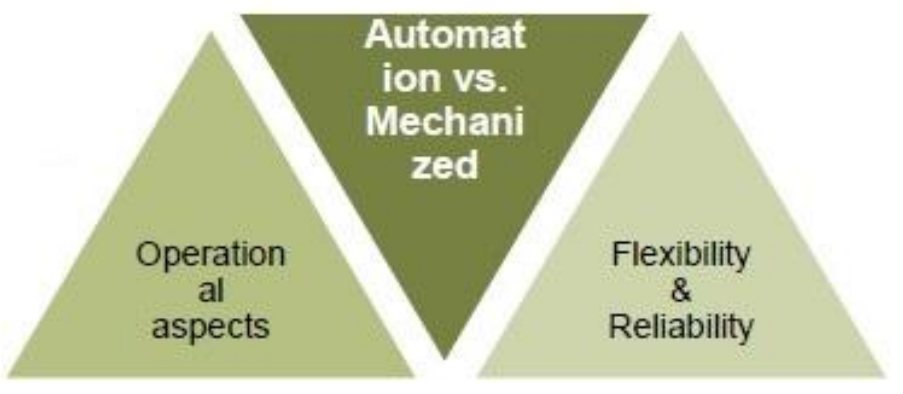

Figure 1. Sorting Technology Criteria 


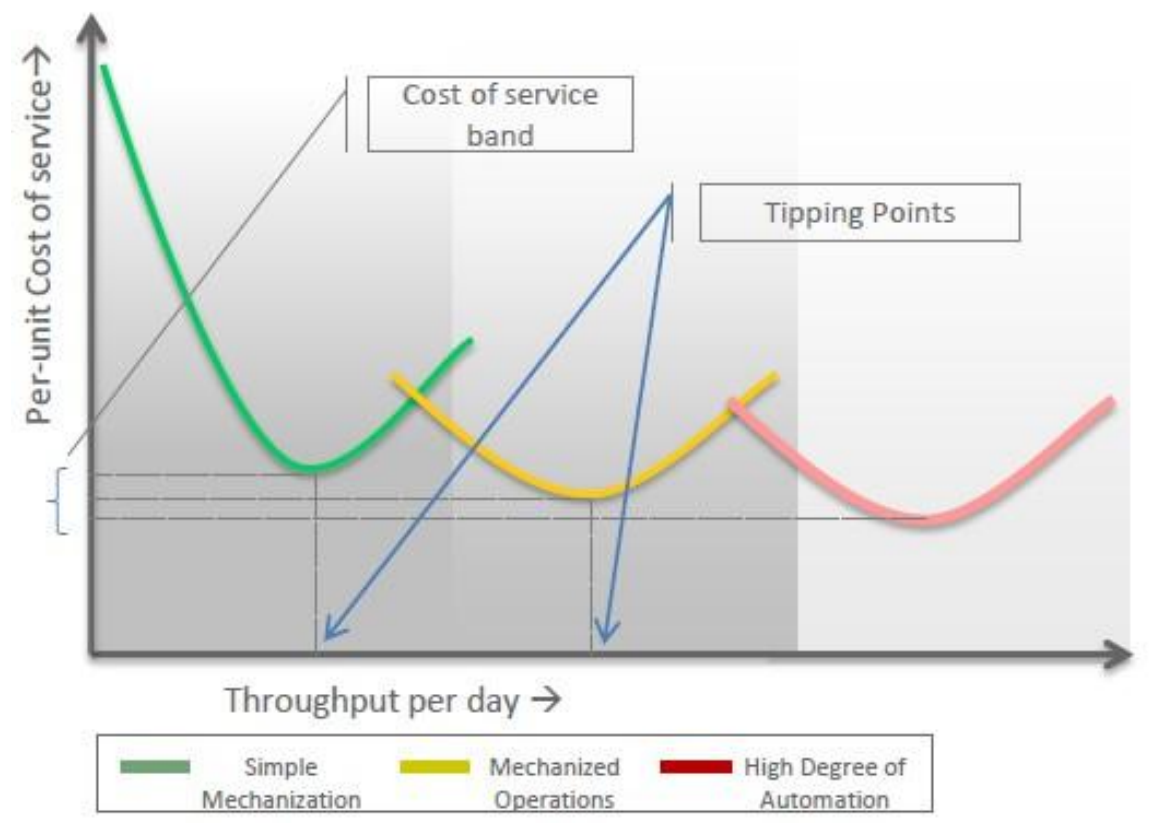

Figure 2. Sorting Technology Curve

The above graph demonstrates the CPS trend with increase in daily demands. While generally the perunit cost of operation will reduce as warehouses move towards greater degree of mechanization and automation, costs are also dependent on local factors. At the same time, awareness of the tipping point is essential to maintain low cost of operation with the promised level of service.

\section{Learnings}

Overlaying other factors linear sorters becomes attractive from $50 \mathrm{~K}$ daily through put onwards

Tilt tray sorters at $100 \mathrm{~K}-250 \mathrm{~K}$ have a range bound cost per shipment under different scenarios

In the $200 \mathrm{~K}-400 \mathrm{k}$ throughput range Cross Belt sorters are better

Significant manpower reduction and higher reliability makes automation more attractive

The final mix for sorting technologies would be derived from the final network model

All of the above are for a 2 shift scenario.

\section{Approaches for Peak Design Capacity}

Sortation Centres need to handle the following 3 types of peaks and there are permanent \& temporary capacity levers to address them

- Intra-day Peak

- Daily Average peak

- $\quad$ Sale month peak

\section{Levers for Capacity Management}

Permanent Capacity Management - Design for highest vs Design for intermediate peak

\section{Temporary Capacity Management -}

\section{SLA Management -}

- $\quad$ Set a higher delivery time promise during the peak season

- Take pre-bookings/ expand from single day to multiple day promotions

Manpower Planning -

- $\quad 3^{\text {rd }}$ shift / Night shift operations using additional temporary staff

- Re-designing resourcing -overstaff for faster operations 
Leveraging 3PL Sorting Centres -

- Enter into partnerships with 3PLs to utilize their spare capacity

- Typically difficult given matching of peaks during the period

\section{Learnings}

Designing for highest peak is 2-2.5 times more expensive than the designing for the second peak

Capacity planning for peak months (Sale) can leverage better SLAs, manpower planning and outsourcing

\section{Solution Map}

\section{Data Basis}

- Taken at network design throughput of $\sim 100,000$ shipments per day for a manual setup for 2 shifts (16 hrs)

- Labour cost linked with throughput ( 90 95\% variable)

- Security and rentals driven only by space ( 100\% fixed)

- Capital Expenditure driven only by installed capacity $(\sim 100 \%$ fixed $)$

- $\quad$ 2nd Peak taken to be 1.5-2 times average daily peak and highest peak 4-4.5 times the average daily peak

\begin{tabular}{|l|l|}
\hline Sort Philosophy & $\begin{array}{l}\text { Sort at destination becomes cheaper } \\
\text { when the sort threshold for a } \\
\text { particular technology or manual setup } \\
\text { is reached } \\
\text { Build flexibility in sorting solution to } \\
\text { sort for optimal number of } \\
\text { destinations at each mother-hub based } \\
\text { on through-put requirement. } \\
\text { Maximize number of sorts at hub } \\
\text { through dynamic bin allocation and } \\
\text { managing in-bound waves. } \rightarrow \text { based } \\
\text { on the load pattern of destinations }\end{array}$ \\
\hline Sort Tailoring & $\begin{array}{l}\text { Local vs. Non local tailoring is } \\
\text { recommended if clubbing of } \\
\text { requirements is not possible. } \rightarrow \\
\text { geographical demand pattern } \\
\text { FA vs Non FA tailoring is governed } \\
\text { solely by business needs \& supply }\end{array}$ \\
\hline
\end{tabular}

\begin{tabular}{|l|l|}
\hline & chain construct. \\
\hline Sorting & $\begin{array}{l}\text { Overlaying other factors linear sorters } \\
\text { becomes attractive from 50K daily } \\
\text { through put onwards } \\
\text { Tilt tray sorters at 100K-250K have a } \\
\text { range bound cost per shipment under } \\
\text { different scenarios } \\
\text { In the 200K-400k throughput range } \\
\text { Cross Belt sorters are better }\end{array}$ \\
\hline $\begin{array}{l}\text { Peak Design } \\
\text { Capacity }\end{array}$ & $\begin{array}{l}\text { Designing for highest peak is 2-2.5 } \\
\text { times more expensive than the } \\
\text { designing for the second peak } \\
\text { Capacity planning for peak months } \\
\text { (Sale) can leverage better SLAs, } \\
\text { manpower planning and outsourcing }\end{array}$ \\
\hline
\end{tabular}

\section{Conclusion}

For a huge, diverse $\&$ growing country like India most of the decisions are based on optimization of resources. The answers the questions raised might change from industry to industry.

\section{Network}

Build flexibility to sort for optimal number of destinations at each mother-hub based on through-put requirement.

Maximize number of sorts at hub through dynamic bin allocation and managing in-bound waves.

\section{Asset}

The final mix for sorting technologies would be derived from the throughput requirement \&final network model

Capacity planning for peak months (Sale) can leverage better SLAs, manpower planning and outsourcing 